\title{
Potentiality of front-face fluorescence spectroscopy to determine the geographic origin of milks from the Haute-Loire department (France)
}

\author{
Romdhane KAROUI ${ }^{\mathrm{a}}$, Bruno MARTIN ${ }^{\mathrm{b}}$, Éric DUFOUR ${ }^{\mathrm{a} *}$ \\ a UR Typicité des Produits Alimentaires, ENITA de Clermont Ferrand, 63370 Lempdes, France \\ b Unité de Recherches sur les Herbivores, INRA, Theix, 63122 Saint-Genès-Champanelle, France
}

Received 15 July 2004 - Accepted 31 January 2005

\begin{abstract}
A total of 40 milk samples, i.e., 8 milks produced in lowland (430-480 m), 16 milks produced in mid-mountain $(720-860 \mathrm{~m})$ and 16 milks produced in mountain $(1070-1150 \mathrm{~m})$ areas of the Haute-Loire department (France), sampled at key periods of animals feeding, were analysed by front-face fluorescence spectroscopy. Tryptophan, aromatic amino acids and nucleic acid $(\mathrm{AAA}+\mathrm{NA})$ and riboflavin fluorescence spectra were recorded in triplicate on different aliquots directly on milks with the excitation wavelengths set at $290 \mathrm{~nm}, 250 \mathrm{~nm}$ and $380 \mathrm{~nm}$, respectively. The excitation spectra of vitamin A were also recorded in triplicate on different aliquots with the emission wavelength set at $410 \mathrm{~nm}$. Using Factorial Discriminant Analysis, 74.1\%, 81.5\% and $76.9 \%$ correct classifications were obtained for the calibration data sets of tryptophan, AAA+NA and riboflavin spectra, respectively. Considering the validation data sets, correct classification of $69.2 \%, 76.9 \%$ and $70.4 \%$ was observed for tryptophan, AAA+NA and riboflavin spectra, respectively. In a second step, the first 5 principal components of the principal component analysis extracted from each data set (tryptophan fluorescence, AAA+NA fluorescence, vitamin A fluorescence and riboflavin fluorescence spectra) were gathered together into one matrix and analysed by factorial discriminant analysis. Correct classifications of 100 and $69.2 \%$ were observed for the calibration and the validation groups, respectively. Milks from the lowlands were well discriminated from the others. It is shown that fluorescence spectra of milks retained information related to the geographic origin. However, the size of the data set should be increased in order to improve the robustness of the algorithm.
\end{abstract}

milk / geographic origin / intrinsic fluorescence / chemometry

Résumé - Potentialité de la spectroscopie de fluorescence frontale pour la détermination de l'origine géographique de laits de Haute-Loire. Un total de 40 laits : 8 laits de plaine (430$480 \mathrm{~m}), 16$ laits de moyenne montagne (720-860 m) et 16 laits de montagne (1070-1150 m), ont été collectés en France (Haute-Loire) à des périodes clés de l'alimentation des animaux. Des spectres de fluorescence des tryptophanes des protéines, des acides aminés aromatiques et acides nucléiques $(\mathrm{AAA}+\mathrm{AN})$ et de la riboflavine ont été enregistrés en triple sur différents aliquots après excitation respectivement à $290 \mathrm{~nm}, 250 \mathrm{~nm}$ et $380 \mathrm{~nm}$. Les spectres d'excitation de la vitamine A ont été enregistrés en triple sur différents aliquots à une longueur d'onde d'émission de $410 \mathrm{~nm}$. Les résultats de l'analyse factorielle discriminante montrent que $74,1 \%, 81,5 \%$ et 76,9\% de bonnes classifications ont été obtenus respectivement pour les jeux de calibration des spectres des tryptophanes, des

\footnotetext{
* Corresponding author: dufour@enitac.fr
} 
$\mathrm{AAA}+\mathrm{AN}$ et de la riboflavine. En ce qui concerne les jeux de validation, des bonnes classifications se montant à $69,2 \%, 76,9 \%$ et 70,4\% ont été observées respectivement pour les spectres des tryptophanes, des AAA+AN et de la riboflavine. Dans une deuxième étape, les 5 premières composantes principales des analyses en composantes principales réalisées sur chaque jeu de données (spectres de fluorescence des tryptophanes des protéines, des AAA+AN, de la vitamine A et de la riboflavine) ont été collées les unes aux autres et l'analyse factorielle discriminante a été appliquée à cette matrice. Les résultats indiquent que $100 \%$ et $69,2 \%$ de bonnes classifications ont été observés respectivement pour les échantillons principaux et de validation. Les laits de plaine sont bien discriminés des laits de moyenne montagne et de montagne. Les résultats montrent que les spectres de fluorescence des laits contiennent des informations relatives à leur origine géographique. Cependant la taille des jeux de données devrait être augmentée afin d'améliorer la robustesse de l'algorithme.

lait / origine géographique / fluorescence intrinsèque / chimiométrie

\section{INTRODUCTION}

Product authenticity and authentication are emerging topics within the food sector [24]. They are a major concern not only of consumers, but also of producers and distributors [17]. Indeed, regulatory authorities, food processors, retailers and consumer groups all have an interest in ensuring that foods are correctly labelled. Many products may be deliberately adulterated, especially those that are expensive and/or subjected to natural fluctuations. With the European harmonisation of the agricultural policy and the emergence of the international markets, authentication of such foodstuffs is the focus of more attention. This trend is the result of efforts made by regional authorities, as well as producers, to protect and support local production. The quality of milk plays a very important role in the production of all types of cheeses, affecting both cheese yield and characteristics of the cheese [39]. In regions with high production costs, agriculture needs to produce food of superior quality. The products can be labelled according to the specific conditions which characterise their origin and the processing technology [2]. These regions can be designated as producing products with Protected Designation of Origin (PDO) or Protected Geographical Indication (PGI).

Animal feeding is one of the elements which is often considered as important by milk producers and food processors [5-7]. Grass of natural highland pastures presents a highly diversified botanical composition as well as abundant secondary metabolites which may influence milk quality [6, 7]. While the gramineae and legumineae families dominate artificial pastures of lowlands, permanent pastures of highlands contain significant proportions of plants belonging to many other botanical families such as rosaceae and plantaginaceae $[6,7,21]$. It has been shown that secondary metabolites (terpenoids) are often abundant in the grass of highland pastures with a highly diversified botanical composition. The relationships between the origin of cheeses and the type of pasture was intensively highlighted by using popular and well-known analytical methods such as gas chromatography, olfactometry or chemical analysis [2, 4, 8, $16,30]$. However, only a few papers have been interested in studying the relationship between grass and milk [6, 11, 31, 35]. Indeed, Fernandez et al. [17] have found by using dynamic head space-gas chromatography coupled to mass spectrometry that milks collected in highland regions were richer in sesquiterpenes than those collected in lowland regions. In addition, Bugaud et al. [6] have shown that the proportion of $\mathrm{C} 18: 1$ and the total of $\mathrm{C} 18: 2+\mathrm{C} 18: 3$ determined by gas chromatography were higher in mountain milks than in valley milks. These methods are tedious and destructive, relatively expensive, time-consuming and require highly skilled operators. Recently, attention has focused on the development of non-invasive and non-destructive instrumental techniques such as front-face fluorescence spectroscopy. Fluorescence spectroscopy is a sensitive and rapid analytical technique that provides information on the presence 
of fluorescent molecules such as tyrosine, phenylalanine and tryptophan residues in proteins, and their environment in biological samples. The fluorescence properties of aromatic amino acids have also been used to study protein structure and protein interactions in dairy products [20]. The potential of using fluorescence in food research has increased during the last few years with the propagated application of chemometrics and with technical and optical developments of spectrofluorimeters. It has been shown that front-face fluorescence spectroscopy can discriminate milk samples subjected to heat treatment from those subjected to homogenisation [13] and monitor structural changes occurring during milk coagulation $[14,18,19]$ and cheese manufacture [20, 32, 33]. In addition, this technique has been used for the determination of lactulose and furosine in milks [28] and the evaluation of oxidative changes in processed cheese during storage [9, 34, 41]. Indeed, Wold et al. [41] have demonstrated that fluorescence properties of riboflavin can be used to measure the degree of degradation of riboflavin in dairy products. Finally, it has been shown that front-face spectroscopy allows the determination of the geographic origin of Gruyère and L'Etivaz PDO cheeses [15, 24] and of Emmental cheeses from different European geographic origins $[23,25,26]$.

Most of the studies regarding the relationship between grass quality and milk have so far been done on bulk milk samples from very small tours (few herds) [6, 12, 31]. Therefore, it would be interesting to validate the relevance on representative milk samples. The Haute-Loire department (France) constitutes a favourable ground. Indeed, even though $95 \%$ of milk is produced in the mountains, the diversity and the production modes remain important because of the very heterogeneous pedo-climatic context. The production zone (HauteLoire) is characterised by its altitude, which varies between 400 and $1300 \mathrm{~m}$. This variation involves varied practices, breeding and fodder systems.

Previous results [25] have shown the ability of tryptophan fluorescence spectra to discriminate between experimental cheeses manufactured with milks originating from 3 different areas in Jura (France). In the present study, front-face fluorescence spectroscopy combined with multivariate statistical methods were used to test whether bulk milk from cows fed a mountain grass, with a highly diversified botanical composition, could be discriminated from bulk milk from cows fed on lowland grass.

\section{MATERIALS AND METHODS}

\subsection{Localisation of the zones of dairy production}

Five dairy production areas, differing both in the altitude and the nature of the rations given to the herd, were studied (Tab. I). For each zone, two collecting tours were organised (10 tours in total). The 10 tours were organised 4 times during 2002 at key periods of animal feeding: the winter period with one tour was carried out at the end of February (P1) when animals were housed. Three other tours were carried out during the grazing period: at the end of May (P2), which corresponded to abundant young grass; at the end of July (P3) and at the end of September (P4), corresponding to the dryness and the regrowth of grass periods, respectively. A total of 40 milk samples, i.e., 8 milks produced in lowland (430$480 \mathrm{~m}), 16$ milks produced in mid-mountain $(720-860 \mathrm{~m})$ and 16 milks produced in mountain (1070-1150 m) areas of the Haute-Loire department (France) were collected. All the samples were frozen and kept at $-20{ }^{\circ} \mathrm{C}$ until the analyses.

\subsection{Fluorescence spectroscopy}

Fluorescence spectra were recorded using a FluoroMax-2 spectrofluorimeter (Spex-Jobin Yvon, Longjumeau, France) mounted with a variable angle front-surface accessory. The incidence angle of the excitation radiation was set at $56^{\circ}$ to ensure that reflected light, scattered radiation, and depolarisation phenomena were minimised. Milk samples were placed in 3-mL quartz cuvette and spectra were recorded at $20^{\circ} \mathrm{C}$. The emission spectra of tryptophan residues 
Table I. Localisation of the French production zones (Haute-Loire department) and animal feeding during winter and summer periods per tour ${ }^{\mathrm{a}}$.

\begin{tabular}{|c|c|c|c|c|c|c|c|c|c|c|}
\hline \multirow{2}{*}{$\frac{\text { Zones }}{\text { Regions }}$} & \multicolumn{4}{|c|}{ Mountain } & \multicolumn{4}{|c|}{ Mid-mountain } & \multicolumn{2}{|c|}{ Lowland } \\
\hline & \multicolumn{2}{|c|}{ Mézenc } & \multicolumn{2}{|c|}{ Velay Volcanique } & \multicolumn{2}{|c|}{ Mont du Forez } & \multicolumn{2}{|c|}{ Velay Granitique } & \multicolumn{2}{|c|}{ Plaine de Brioude } \\
\hline Altitude (m) & \multicolumn{2}{|c|}{1150} & \multicolumn{2}{|c|}{1070} & \multicolumn{2}{|c|}{860} & \multicolumn{2}{|c|}{720} & \multicolumn{2}{|c|}{450} \\
\hline Tours & M1 & M2 & V1 & V2 & F1 & F2 & G1 & G2 & B1 & B2 \\
\hline \multicolumn{11}{|c|}{ Winter period (P1) } \\
\hline \multicolumn{11}{|l|}{$\begin{array}{l}\text { Basic ration according } \\
\text { to the nature of flora }\end{array}$} \\
\hline Permanent pasture $(\%)$ & $100(0)$ & $93(12)$ & $52(27)$ & $27(28)$ & $45(28)$ & $36(34)$ & $22(40)$ & $21(36)$ & $15(20)$ & $24(18)$ \\
\hline temporary pasture (\%) & $0(0)$ & $7(12)$ & $48(26)$ & 73 (29) & $45(28)$ & $64(34)$ & $42(30)$ & $44(26)$ & $15(23)$ & $23(13)$ \\
\hline Maize silage (\%) & $0(0)$ & $0(0)$ & $0(0)$ & $0(0)$ & $10(16)$ & $0(0)$ & $36(22)$ & $35(23)$ & $70(27)$ & $53(25)$ \\
\hline \multicolumn{11}{|l|}{$\begin{array}{l}\text { Basic flora according } \\
\text { to the mode of forage } \\
\text { conservation }\end{array}$} \\
\hline Hay $(\%)$ & $82(25)$ & $48(13)$ & $42(25)$ & $32(31)$ & $41(26)$ & $39(31)$ & $21(34)$ & $18(30)$ & $18(25)$ & $14(21)$ \\
\hline Wrapped forage (\%) & $18(25)$ & $52(13)$ & $32(31)$ & $24(37)$ & $18(25)$ & $32(30)$ & $4(26)$ & $4(11)$ & $3(16)$ & $1(3)$ \\
\hline Grass silage (\%) & $0(0)$ & $0(0)$ & $26(30)$ & $44(36)$ & $31(26)$ & $29(27)$ & $39(28)$ & $43(21)$ & $9(19)$ & $32(9)$ \\
\hline Maize silage (\%) & $0(0)$ & $0(0)$ & $0(0)$ & $0(0)$ & $10(16)$ & $0(0)$ & $36(22)$ & $35(23)$ & $70(27)$ & $53(25)$ \\
\hline $\begin{array}{l}\text { Concentrates } \\
\left(\mathrm{kg} \cdot \mathrm{cow}^{-1} \cdot \mathrm{day}^{-1}\right)\end{array}$ & $3.1(1.6)$ & $3.4(0.7)$ & $5(1.7)$ & $5.1(1.4)$ & $5.3(1.8)$ & $4.6(1.5)$ & $4.3(1.1)$ & $4.7(1.4)$ & $3.2(1.5)$ & $5.1(2.0)$ \\
\hline
\end{tabular}

Summer period (P2, P3, P4)

\begin{tabular}{|c|c|c|c|c|c|c|c|c|c|c|}
\hline \multicolumn{11}{|l|}{$\begin{array}{l}\text { Basic ration according } \\
\text { to the nature of flora }\end{array}$} \\
\hline Permanent pasture (\%) & 99 (3) & $94(14)$ & $71(32)$ & $56(33)$ & $66(38)$ & $63(35)$ & $48(39)$ & $62(30)$ & $42(23)$ & $28(34)$ \\
\hline temporary pasture (\%) & $0(0)$ & $5(14)$ & $29(32)$ & $44(33)$ & $33(38)$ & $36(36)$ & $40(40)$ & $29(29)$ & $25(25)$ & $38(26)$ \\
\hline Maize silage (\%) & $1(3)$ & $1(2)$ & $0(0)$ & $0(0)$ & $0(0)$ & $1(5)$ & $12(14)$ & $9(12)$ & $33(25)$ & $34(20)$ \\
\hline \multicolumn{11}{|l|}{$\begin{array}{l}\text { Basic flora according } \\
\text { to the mode of forage } \\
\text { conservation }\end{array}$} \\
\hline Grass grazed & $79(12)$ & $75(12)$ & $63(19)$ & $63(19)$ & $78(19)$ & $79(18)$ & $73(21)$ & $64(19)$ & $51(21)$ & $45(23)$ \\
\hline Hay $(\%)$ & $20(11)$ & $22(11)$ & $33(17)$ & $27(15)$ & $16(14)$ & $15(16)$ & $13(14)$ & $15(16)$ & $7(9)$ & $12(15)$ \\
\hline Wrapped forage (\%) & $0(0)$ & $2(4)$ & $4(10)$ & $6(13)$ & $4(13)$ & $4(9)$ & $1(2)$ & $4(7)$ & 1 (n.d.) & 1 (n.d.) \\
\hline Grass silage (\%) & $0(0)$ & $0(0)$ & $0(0)$ & $4(8)$ & $2(5)$ & 1 (n.d.) & $1(4)$ & $8(11)$ & $8(14)$ & $7(7)$ \\
\hline Maize silage (\%) & $1(3)$ & $1(2)$ & $0(0)$ & $0(0)$ & $0(0)$ & $1(5)$ & $12(14)$ & $9(12)$ & $33(25)$ & $35(20)$ \\
\hline
\end{tabular}

Concentrates

$\left(\mathrm{kg} \cdot \mathrm{cow}^{-1} \cdot \mathrm{day}^{-1}\right)$

a Average values of the quantities of milk collected from agriculture; (): standard deviation.

$(305-400 \mathrm{~nm})$ and aromatic amino acids + nucleic acid (AAA+NA) $(280-480 \mathrm{~nm})$ were recorded with the excitation wavelengths set at $290 \mathrm{~nm}$ and $250 \mathrm{~nm}$, respec- tively. The emission fluorescence spectra $(400-640 \mathrm{~nm})$ of riboflavin were recorded with excitation set at $380 \mathrm{~nm}$. The excitation spectra of vitamin A $(250-350 \mathrm{~nm})$ 
were recorded with the emission wavelength set at $410 \mathrm{~nm}$. All spectra were corrected for instrumental distortions in excitation using a rhodamine cell as a reference channel. For each milk, three spectra were recorded on different aliquots.

\subsection{Mathematical treatment of data}

\subsubsection{Principal Component Analysis (PCA)}

Fluorescence spectra were normalised by reducing the area under each spectrum to a value of 1 , according to Bertrand and Scotter [1]. PCA was applied to the normalised spectra in order to investigate differences in the spectra $[18,20]$. This statistical multivariate treatment made it possible to draw similarity maps of the samples $[1,22]$.

\subsubsection{Factorial Discriminant Analysis (FDA)}

Factorial Discriminant Analysis (FDA) was performed on the first 5 principal components (PCs) resulting from the PCA applied to the fluorescence spectral data (tryptophan, AAA+NA, riboflavin or vitamin A). The aim of this technique was to predict the membership of an individual to a qualitative group defined as a preliminary [36]. A group was created for each type of milk, i.e., milk produced in lowland, midmountain and mountain areas. FDA could not be applied in a straightforward way to continuous spectra because of the high correlations occurring between the wavelengths.

FDA assesses new synthetic variables called "discriminant factors", which are linear combinations of the selected principal components, and allows a better separation of the centres of gravity of the considered groups. The individual milk samples could be reallocated within the various groups. For each sample, the distance from the various centres of gravity of the groups was calculated. The sample was assigned to the group where the distance between the centres of gravity was the shortest. Comparison of the assigned group to the real group was an indicator of the quality of the discrimi- nation. Similarity maps could be drawn, in analogy to those drawn for PCA. Each of the data sets used contained 40 spectra, where each spectrum is the average of the triplicate recorded on each milk sample. The fluorescence spectral data were divided into two data sets for calibration and validation. Calibration and validation data sets were obtained by splitting the spectral collection (i.e., milks produced in lowland, mid-mountain and mountain regions). For each geographic area, two-third of the spectra were put in the calibration group and one-third was used to create the validation group.

\subsubsection{Concatenation of the fluorescence spectral data}

Finally, the first 5 PCs of the PCA performed on each of the 4 data sets (i.e., tryptophan fluorescence, AAA+NA fluorescence, riboflavin fluorescence and vitamin A fluorescence spectra) were pooled into one matrix and this new table was analysed by FDA. This concatenation approach helped to improve the discrimination between milks by using a number of different fluorescence spectra, as well as to assess the ability of fluorescence spectroscopy to determine the geographic origin of milks independently of their production periods.

PCA and FDA were carried out using StatBoxPro (Grimmer logiciels, Paris, France).

\section{RESULTS AND DISCUSSION}

The recorded fluorescence spectra give information regarding molecules containing conjugated double bounds. Aromatic amino acids and nucleic acids, tryptophan residues of proteins, vitamin A and riboflavin are the best known fluorescent molecules in milk. However, milks also contain many other compounds that may fluoresce: e.g., conjugated linoleic acid (CLA), phenolic compounds, terpenoids or aromatic acids $[2,3,37,38]$. So a spectrum recorded on a milk sample following excitation at $250 \mathrm{~nm}$ or $290 \mathrm{~nm}$ included information on several fluorophores and may be considered 


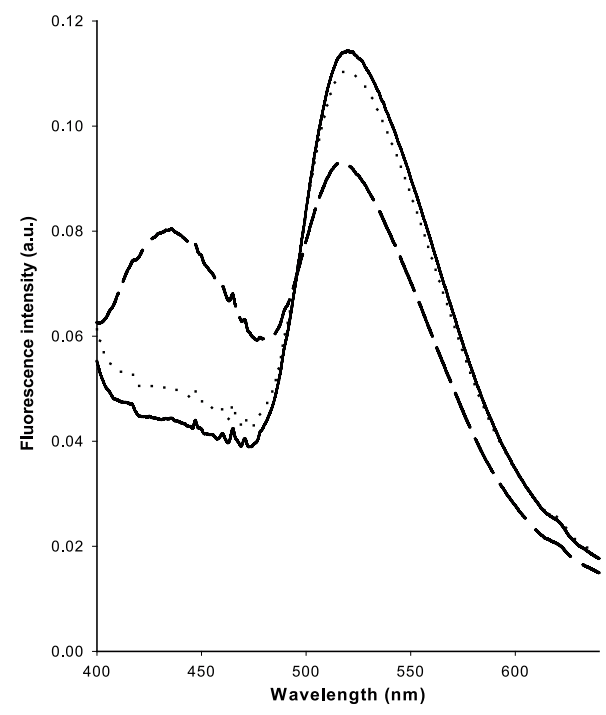

Figure 1. Riboflavin fluorescence spectra of milks produced in lowland (_ _ _ ), mid-mountain $(-)$ and mountain $(. . .$.$) areas.$

as a characteristic fingerprint which allows the sample to be identified [20, 25]. In addition, emission spectra with excitation set at $380 \mathrm{~nm}$ were recorded. Indeed, the emission spectra of riboflavin have been used to determine the degree of oxidation of milks and cheeses [9, 34, 41]. Excitation spectra with emission at $410 \mathrm{~nm}$ were also considered since the excitation spectrum of vitamin A has the ability to discriminate cheeses according to their varieties and ripening age [20, 29, 33].

The tryptophan and AAA+NA fluorescence spectra of the different milks exhibited a maximum located at $340 \mathrm{~nm}$ (data not shown). Considering vitamin A, the shape of the spectra showed two maxima at 320 and $305 \mathrm{~nm}$ and a shoulder at $295 \mathrm{~nm}$ (data not shown).

Riboflavin emission spectra of the investigated milks showed the largest differences according to their geographical origin (Fig. 1). From the riboflavin spectra, there are two spectral regions that are of particular interest: the broad peak at about $520 \mathrm{~nm}$ which corresponds to the green/yellow col- our and the region between 405 and $480 \mathrm{~nm}$, which is in the violet and blue regions. It appeared that milks produced in midmountains and mountains presented intense fluorescence at about $520 \mathrm{~nm}$, and correspondingly low fluorescence in the violet region [41].

As a result of the small differences and the complexity of the spectra, univariate analysis was not really appropriate to statistically analyse the data sets. Multivariate statistical techniques such as PCA and FDA make it possible to extract information related to the origin of the differences between spectra.

\subsection{Milk discrimination based on tryptophan and AAA+NA fluorescence spectra}

The ability of tryptophan or AAA+NA fluorescence spectra to differentiate between the three groups of milks was investigated by applying FDA to the first 5 PCs of the PCA performed on tryptophan and AAA+NA fluorescence spectra. Three groups were created for the investigated milks (lowland, mid-mountain and mountain). Considering tryptophan fluorescence spectra, the map defined by the discriminant factors 1 and 2 took into account $100 \%$ of the total variance with discriminant factor 1 accounting for $73.4 \%$ (Fig. 2). Considering discriminant factor 1 , milks from the mountains were observed on the left, whereas milks from the lowlands were observed on the right. The milks from the mid-mountain regions presented on the map co-ordinates close to the origin and partly overlapped mountain and lowland samples. Correct classification amounting to $74.1 \%$ and $69.2 \%$ was observed for the calibration and the validation sets (Tab. II), respectively. Table II shows that some misclassifications occurred between milks from the mountain and midmountain. For milks produced in the mountain, two samples were classified as belonging to the mid-mountain group. $100 \%$ correct classification was observed for milks produced in lowland areas.

Considering AAA+NA fluorescence spectra, the map defined by the discriminant factors 1 and 2 took into account $100 \%$ 


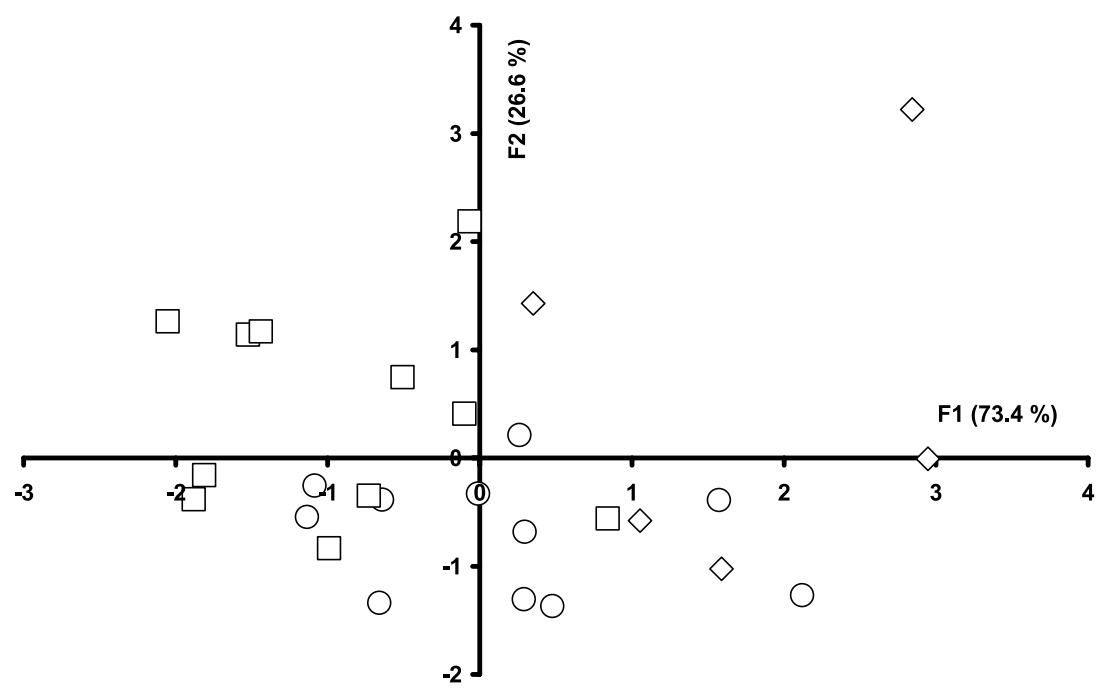

Figure 2. Discriminant analysis similarity map determined by discriminant factors 1 and 2 for tryptophan fluorescence spectra of milks produced in lowland $(\diamond)$,mid-mountain $(O)$ and mountain $(\square)$ areas.

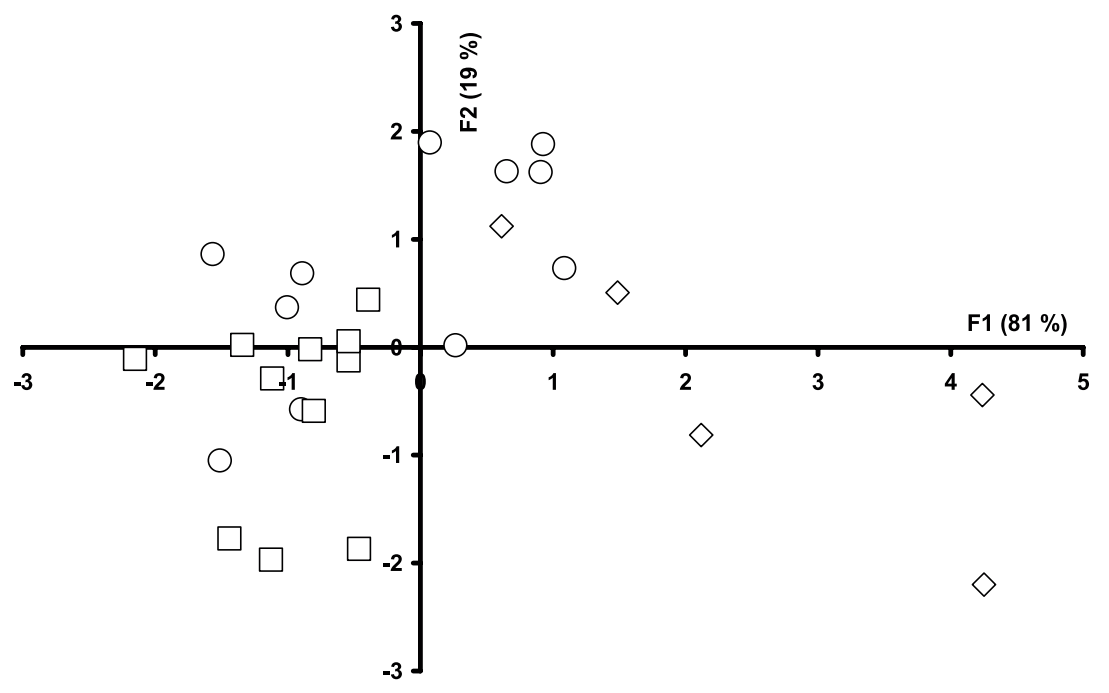

Figure 3. Discriminant analysis similarity map determined by discriminant factors 1 and 2 for aromatic amino acid and nucleic acid fluorescence spectra of milks produced in lowland $(\diamond)$, mid-mountain $(O)$ and mountain $(\square)$ areas.

of the total variance with discriminant factor 1 accounting for $81 \%$ (Fig. 3). Correct classifications amounting to $81.5 \%$ and $76.9 \%$ were observed for the calibration and the validation groups, respectively.
Table II gives the classification of the validation group for the different milks. This table illustrates that milks from the mountain were discriminated from milks produced from the lowlands: only 1 of the 5 mountain 
Table II. Classification table for milks from the Haute-Loire department based on tryptophan, aromatic amino acids + nucleic acids, vitamin $\mathrm{A}$ and riboflavin fluorescence validation data sets.

\begin{tabular}{lccccc}
\hline \multicolumn{1}{c}{ Predicted $^{\mathrm{a}}$} & Lowlands & Mid-mountains & Mountains & \% correct classification \\
\hline Real & & Tryptophan fluorescence spectra & \\
Lowland & $\mathbf{3}$ & - & - & 100 \\
Mid-mountain & - & $\mathbf{3}$ & 2 & 60 \\
Mountain & - & 2 & $\mathbf{3}$ & 60 \\
Total & - & - & - & $\mathbf{6 9 . 2}$
\end{tabular}

Aromatic amino acids and nucleic acids fluorescence spectra

$\begin{array}{lcccc}\text { Lowland } & \mathbf{2} & 1 & - & 66.7 \\ \text { Mid-mountain } & - & \mathbf{4} & 1 & 80 \\ \text { Mountain } & - & 1 & \mathbf{4} & 80 \\ \text { Total } & - & - & - & \mathbf{7 6 . 9} \\ & & \text { Vitamin A fluorescence spectra } & & \\ \text { Lowland } & \mathbf{3} & - & - & 100 \\ \text { Mid-mountain } & - & \mathbf{3} & 2 & 60 \\ \text { Mountain } & - & 4 & \mathbf{1} & 20 \\ \text { Total } & - & - & - & \mathbf{5 3 . 8} \\ & & \text { Riboflavin fluorescence spectra } & & \\ \text { Lowland } & \mathbf{2} & 1 & - & 66.7 \\ \text { Mid-mountain } & & \mathbf{4} & 1 & 80 \\ \text { Mountain } & - & 2 & \mathbf{3} & 60 \\ \text { Total } & - & - & - & \mathbf{7 0 . 4}\end{array}$

a The number of milks predicted from the model; ${ }^{\mathrm{b}}$ The number of real milks.

milks was classified as mid-mountain milk. The worst classification was observed for milks produced in lowland areas, since only $66.7 \%$ correct classification was obtained (Tab. II). Indeed, one milk was classified as belonging to the mid-mountain group. From the results obtained from tryptophan and AAA+NA fluorescence spectra, it was shown that misclassification occurred, on one hand, between milks from the mountain and mid-mountain, and on the other hand, between milks from mid-mountain and lowland areas. This discrepancy could be explained by the heterogeneity of the loca- tion of the farms in the mid-mountain area which varies in altitude between $720 \mathrm{~m}$ and $860 \mathrm{~m}$, whereas the altitudes of the farms of the lowland areas and mountain were more homogeneous and located at about 460 and $1100 \mathrm{~m}$, respectively. Another explanation could be due to the effect of the season on the composition of the milk and the environment of the considered fluorophores.

The differences observed in the spectra recorded following excitation at 250 or $290 \mathrm{~nm}$ on milks produced from the lowland and mountain areas may also originate from the contribution of other intrinsic fluorescent 


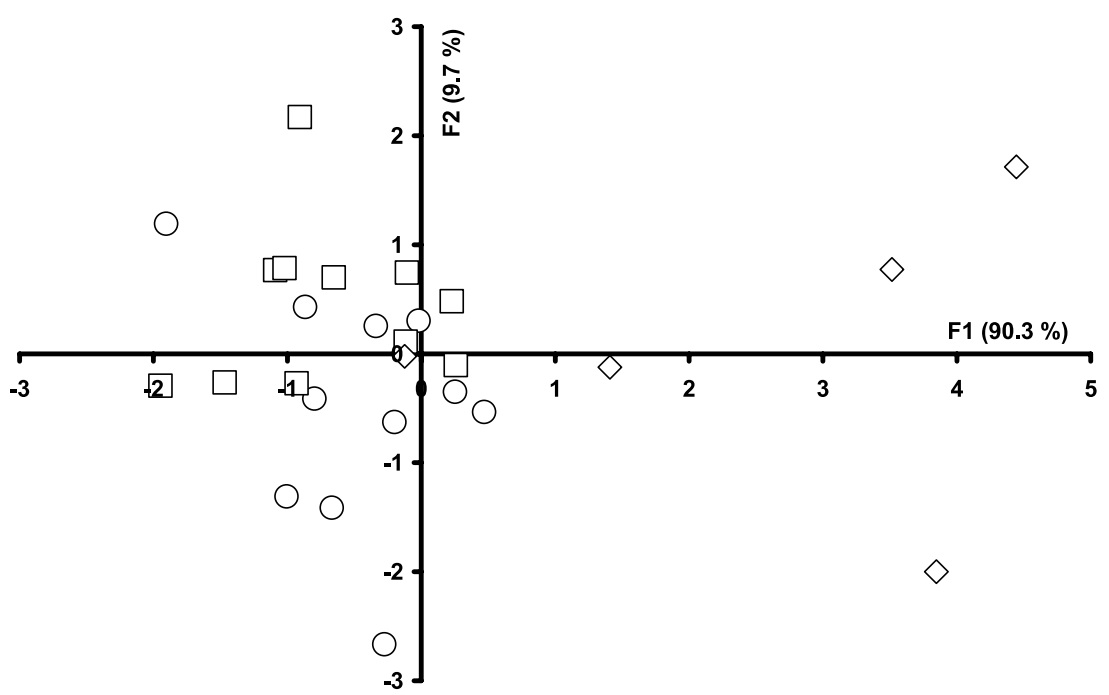

Figure 4. Discriminant analysis similarity map determined by discriminant factors 1 and 2 for vitamin A fluorescence spectra of milks produced in lowland $(\diamond)$, mid-mountain $(O)$ and mountain $(\square)$ areas.

probes than tryptophan or AAA+NA. Indeed, several fluorescent molecules can be excited at 250 and/or $290 \mathrm{~nm}$. In the current study, the occurrence of potentially fluorescent terpenes such as $p$-cymene could contribute to the fluorescence spectra of milks $[2,25]$. It has been reported that the terpenes are found in milks produced in the highlands, but they are almost absent in the dairy products from the lowlands $[2,40]$.

\subsection{Milk discrimination based on vitamin A fluorescence spectra}

FDA was applied to the first 5 PCs of the PCA performed on the vitamin A fluorescence spectra. The approach described in Section 3.1 was also used in this case, i.e., three groups were created. The map defined by the discriminant factors 1 and 2 is shown in Figure 4. Considering the discriminant factor 1 , which accounted for $90.3 \%$ of the total variance, milks from the lowlands had positive score values, whereas milks from the mid-mountains and mountains had mostly negative score values. Correct clas- sification was observed for 70.4 and $53.8 \%$ of the calibration and validation samples, respectively (Tab. III).

Conjugated linoleic acid (CLA), which is an intermediate product in the biohydrogenation of linoleic acid and other polyunsaturated fatty acids from plants in the rumen of the cow by the bacteria Butyrovibrio fibrisolvum [27, 42], could also explain the difference in the shape of the excitation spectra recorded following emission at 410 $\mathrm{nm}$. Factors affecting the milk fat content of CLA have been reviewed and animal breed, feeding regime, age of animals and season play major roles [11]. Previous investigations have also observed substantial variations in the milk fat content of CLA depending on the altitude [10].

\subsection{Milk discrimination based on riboflavin fluorescence spectra}

PCA was applied to the riboflavin fluorescence spectra recorded on the milks. The map defined by PC1 and PC2 showed the best discrimination of the lowland milks 


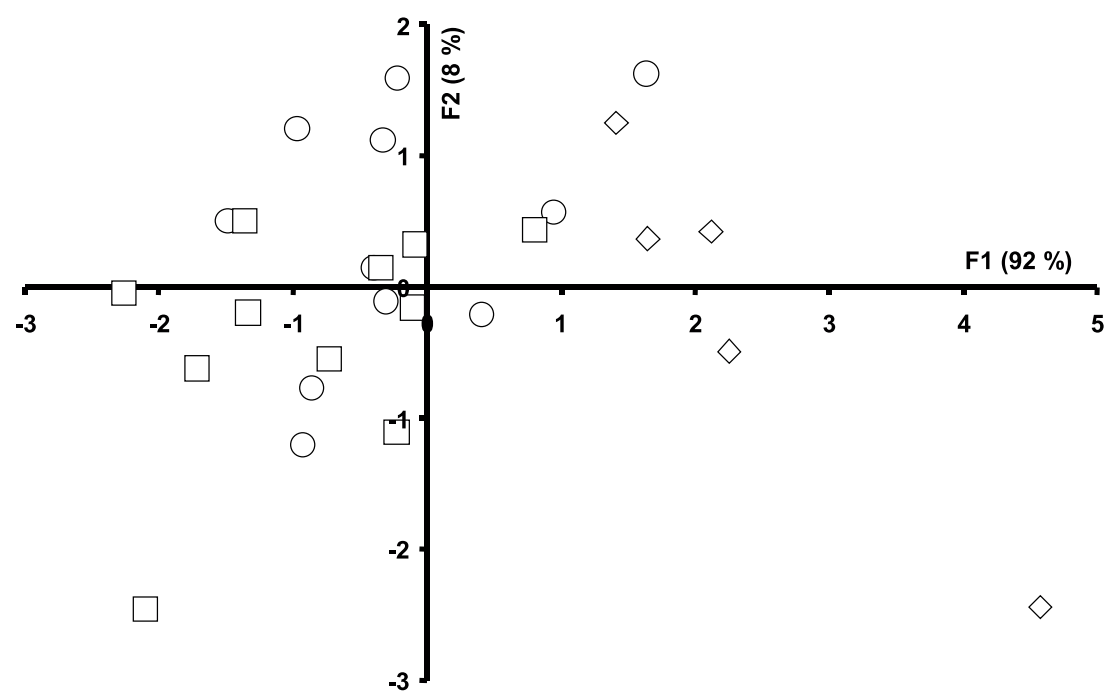

Figure 5. Discriminant analysis similarity map determined by discriminant factors 1 and 2 for riboflavin fluorescence spectra of milks produced in lowland $(\diamond)$, mid-mountain $(O)$ and mountain $(\square)$ areas.

Table III. Classification table for the spectra of the validation group. FDA performed on the concatenated first 5 principal components of the PCA performed on the 4 fluorescence spectral data sets.

\begin{tabular}{|c|c|c|c|c|}
\hline Real $^{\mathrm{b}}$ Predicted $^{\mathrm{a}}$ & Lowland & Mid-mountain & Mountain & $\%$ well classified \\
\hline Lowland & 3 & - & - & 100 \\
\hline Mid-mountain & - & 3 & 2 & 60 \\
\hline Mountain & - & 2 & 3 & 60 \\
\hline Total & - & - & - & 69.2 \\
\hline
\end{tabular}

a The number of milks predicted from the model; ${ }^{b}$ The number of real milks.

from the mid-mountain and mountain milks. Indeed, milks from the lowlands had negative scores values considering PC1, whereas the other milks presented mostly positive score values. Then, FDA was applied to the first $5 \mathrm{PCs}$ and the map defined by discriminant factors 1 and 2 is shown in Figure 5. Considering discriminant factor 1 accounting for $92 \%$ of the total variance, milks from the lowlands were observed on the right, whereas milks from the mountains were located on the left. Again, milks produced in the mid-mountain presented co-ordinates close to the origin and were not well discriminated from the other milks.

Correct classification was obtained for $76.9 \%$ and $70.4 \%$ of the calibration and the validation spectra, respectively (Tab. II). Considering milks from the lowlands, only 1 sample was classified as belonging to mid-mountain milks. For milks produced in 


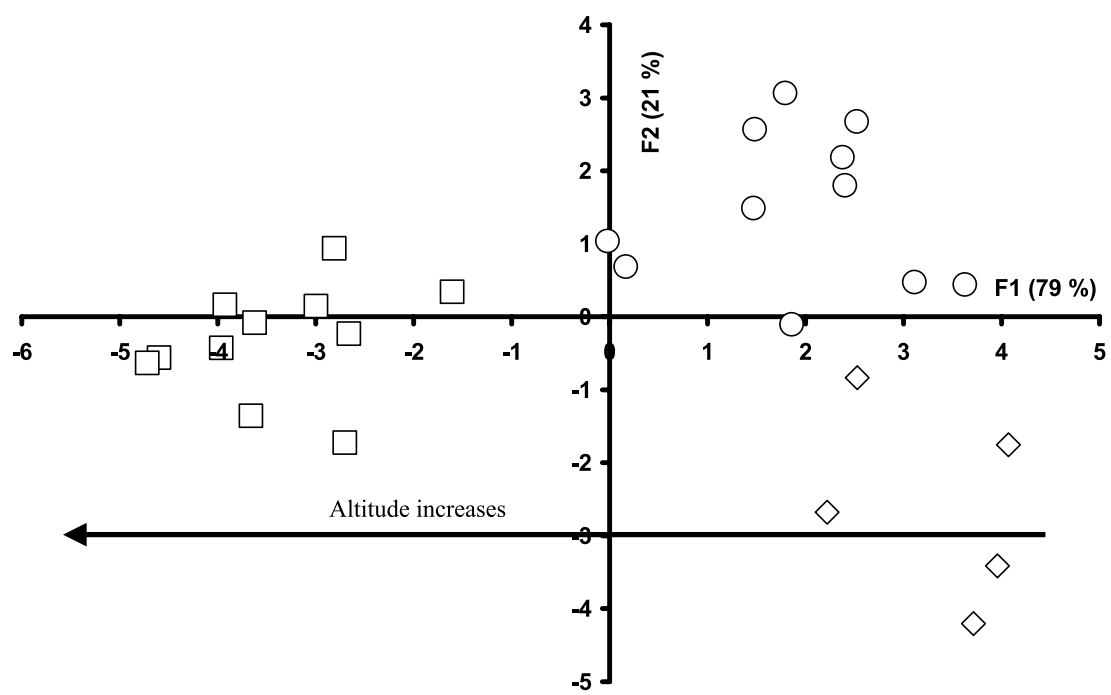

Figure 6. Discriminant analysis similarity maps determined by discriminant factors 1 and 2. FDA performed on the first 5 concatenated PCs of PCA performed on the 4 fluorescence spectral data sets of the investigated milks produced in lowland $(\diamond)$, mid-mountain regions $(O)$ and mountain $(\square)$ areas.

the mid-mountains, $100 \%$ correct classification was observed. Finally, regarding milks from the mountain, two milks were assigned to the mid-mountain group.

\subsection{Global analysis of the fluorescence spectral data recorded on the milks: concatenation}

Milk is a complex product which contains many fluorescent molecules. The data sets obtained for the investigated probes during this study contain information on the milks which can be complementary. Consequently, a better discrimination of milks could be obtained by jointly studying the various spectral data. This combined analysis can be performed by using the technique of concatenation. Thus, the first $5 \mathrm{PCs}$ of the PCA applied to each of the four data sets were gathered into one matrix (20 variables) and this table was analysed by FDA.

The map defined by the discriminant factors 1 and 2 represented $100 \%$ of the total variance with discriminant factor 1 accounting for $79 \%$ of the total variance (Fig. 6). Milks were discriminated according to dis- criminant factor 1: considering this axis, milks from the lowlands were observed on the far right, whereas milks from the mountains were located on the far left. Milks produced in the mid-mountain had co-ordinates close to the origin. It appears that such coupling is appropriate for the discrimination of milks according to their geographical origin.

Correct classification was observed for $100 \%$ (data not shown) and 69.2\% (Tab. III) of the calibration and validation samples, respectively. Table III gives the classification of the validation spectra for the three groups. This table shows $100 \%$ correct classification for milks from the lowlands. Two milks produced in the mid-mountains were misclassified as belonging to milks produced in the lowlands. This result could be explained by the close altitudes of certain tours which are nevertheless classified into 2 different groups: mountain or mid-mountain.

It appeared that the approach using concatenation of the four data sets allowed us to manage in a very efficient way all of the spectroscopic information collected on the 
milks. Each of the investigated probes provides information which can be used for recognising the geographic origin of such milks. The concatenation method sums up the whole lot of this information in two discriminant factors (F1 and F2), taking into account the relation between the different data tables. These results, which were not obtained by FDA performed on each of the tryptophan, AAA+NA, vitamin A or riboflavin fluorescence spectral data sets, showed that the concatenation methodology allowed the use of all the spectroscopic information given by the four intrinsic probes in a very efficient way. The current study is in agreement with previously published data, indicating that fluorescence spectra can be used for the determination of the geographic origin of Gruyère PDO and L'Etivaz PDO cheeses [15] and of European Emmental cheeses [23, 24].

\section{CONCLUSION}

Rapid fluorescence measurements applied directly on milks have been used for monitoring the geographic origin of HauteLoire milks. The results obtained suggest the potential of this spectroscopic method coupled with chemometrics for the discrimination of milks. Although many factors influence the final quality of milks such as the season and the composition of fodder consumed by the cow, the results are promising and confirmed the interest of the joint analysis (concatenation) of fluorescence spectra. In addition, the simplicity of the method (i.e., rapid and non-invasive) offers rich opportunities for efficient characterisation of milks.

With only 40 independent samples in each data set, the current model is not very robust against the inclusion or exclusion of samples. Providing that the size of the data sets is increased in order to improve the robustness of the algorithm, fluorescence spectroscopy could assist in solving problems linked with the determination of the geographical origin of milks in relation to the wide variations of pastures.
Acknowledgements: The authors would like to thank D. Teissier ("Chambre d'Agriculture de la Haute-Loire") for the supply of the milk samples.

\section{REFERENCES}

[1] Bertrand D., Scotter C.N.G., Application of multivariate analyses to NIR spectra of gelatinized starch, Appl. Spectrosc. 46 (1992) 1420-1425.

[2] Bosset J.O., Berger T., Bühler-Moor U., Bütikofer U., Collomb M., Dafflon O., Gauch R., Jeangros B., Lavanchy P., Mariaca R., Schovic J., Sieber R., Troxler J., Comparison of some highland and lowland Gruyère type cheese of Switzerland: a study of their potential PDO/AOC/AOP characteristics. Authenticity and adulteration of food- The analytrical approach, in: IX. Proceedings of European Food Chemistry, Vol. 2, FECSEvent $N^{\circ} 220,1997$, pp. 395-400.

[3] Bosset J.O., Bütikofer U., Dafflon O., Koch H., Scheurer L., Sieber R., Teneur en hydrocarbures aromatiques polycycliques de fromages avec et sans goût de fumée, Sci. Aliments 18 (1998) 347-359.

[4] Bosset J.O., Jeangros B., Berger Th., Bütikofer U., Collomb M., Gauch R., Lavanchy P., Scehovic J., Troxler J., Sieber R., Comparaison de fromages à pâte dure de type Gruyère produits en région de montagne et de plaine, Rev. Suisse Agric. 31 (1999) 17-22.

[5] Buchin S., Martin B., Dupont D., Bornard A., Achilleos C., Influence of the composition of Alpine highland pasture on the chemical, rheological and sensory properties of cheese, J. Dairy Res. 66 (1999) 579-588.

[6] Bugaud C., Buchin C., Coulon J.B., Hauwuy A., Dupont D., Influence of the nature of alpine pastures on plasmin activity, fatty acid and volatile compound composition of milk, Lait 81 (2001) 401-404.

[7] Bugaud C., Buchin S., Noël Y., Tessier L., Pochet S., Martin B., Chamba J.F., Relationships between Abondance cheese texture and that of milk produced by cows grazing different types of pastures, Lait 81 (2001) 593-607.

[8] Carpino S., Acree T.E., Barbano D.M., Licitra G., Siebert K.J., Chemometric analysis of Ragusano cheese flavor, J. Sci. Food Agric. 50 (2002) 1143-1149.

[9] Christensen J., Povlsen V.T., Sørensen J., Application of fluorescence spectroscopy and chemometrics in the evaluation of processed cheese during storage, J. Dairy Sci. 86 (2003) 1101-1107. 
[10] Collomb M., Bütikofer U., Sieber R., Bosset J.O., Jeangros B., Conjugated linoleic acid composition of cow's milk fat produced in lowlands and highlands, J. Dairy Res. 68 (2001) 519-523.

[11] Collomb M., Bütikofer U., Sieber R., Jeangros B., Bosset J.O., Composition of fatty acids in cow's milk fat produced in the lowlands, mountains and highlands of Switzerland using high-resolution gas chromatography, Int. Dairy J. 12 (2002) 649-659.

[12] Coulon J.B., Delacroix-Buchet A., Martin B., Pirisi A., Relationships between ruminant management and sensory characteristic of cheeses: a review, Lait 84 (2004) 221-241.

[13] Dufour E., Riaublanc A., Potentiality of spectroscopic methods for the characterisation of dairy products. I. Front-face fluorescence study of raw, heated and homogenised milks, Lait 77 (1997) 657-670.

[14] Dufour E., Lopez C., Riaublanc A., Mouhous Riou N., La spectroscopie de fluorescence frontale: une approche non invasive de la structure et des interactions entre les constituants des aliments, in: Proceedings $\mathrm{X}$. Rencontres Agoral, Massy, France, 1998, pp. 209-215.

[15] Dufour E., Karoui R., Bosset J.O., Utilisation de la fluorescence frontale intrinsèque de fromages de type L'Etivaz AOC et Gruyère AOC pour reconnaître leur origine géographique, Trav. Chim. Aliment. Hyg. 94 (2003) 379-393.

[16] Dumont J.P., Adda J., Occurrence of sesquiterpenes in mountain cheeses volatiles, J. Agric. Food Chem. 26 (1978) 364-367.

[17] Fernandez C., Astier C., Rock E., Coulon J.B., Berdagué J.L., Characterization of milk by analysis of its terpene fractions, Int. J. Food Sci. Tech. 38 (2003) 445-451.

[18] Herbert S., Caractérisation de la structure moléculaire et microscopique de fromages à pâte molle. Analyse multivariée des données structurales en relation avec la texture, Thèse Ecole Doctorale Chimie Biologie de l'Université de Nantes, France, 1999.

[19] Herbert S., Riaublanc A., Bouchet B., Gallant D.J., Dufour E., Fluorescence spectroscopy investigations of acid-and rennet-induced milk coagulation of milk, J. Dairy Sci. 82 (1999) 2056-2062.

[20] Herbert S., Mouhous Riou N., Devaux M.F., Riaublanc A., Bouchet B., Gallant J.D., Dufour E., Monitoring the identity and the structure of soft cheeses by fluorescence spectroscopy, Lait 80 (2000) 621-634.

[21] Jeangros B., Scehovic J., Troxler J., Bachmann H.J., Bosset J.O., Comparaison de caractéristiques botaniques et chimiques d'herbages pâturés en plaine et en montagne, Fourrages 159 (1999) 277-292.

[22] Jolliffe I.T., Principal Component Analysis, Springer, New-York, USA, 1986.

[23] Karoui R., Dufour E., Pillonel L., Picque D., Cattenoz T., Bosset J.O., Fluorescence and infrared spectroscopies: a tool for the determination of the geographic origin of Emmental cheeses manufactured during summer, Lait 84 (2004) 359-374.

[24] Karoui R., Dufour E., Pillonel L., Picque D., Cattenoz T., Bosset J.O., Determining the geographic origin of Emmental cheeses produced during winter and summer using a technique based on the concatenation of MIR and fluorescence spectroscopic data, Eur. J. Food Res. Technol. 219 (2004) 184-189.

[25] Karoui R., Bosset J.O., Mazerolles G., Kulmyrzaev A., Dufour E., Monitoring the geographic origin of both experimental French Jura hard cheeses and Swiss Gruyère and l'Etivaz PDO cheeses using mid-infrared and fluorescence spectroscopies, Int. Dairy J. 15 (2005) 275-286.

[26] Karoui R., Dufour E., Pillonel L., Scaller E., Picque D., Cattenoz T., Bosset J.O., Determination of the geographic origin of Emmental cheeses by combining infrared and fluorescence spectroscopies, Int. Dairy J. 15 (2005) 287-298.

[27] Kepler C.R., Hirons K.P., McNeill J.J., Tove S.B., Intermediates and products of the biohydrogenation of linoleic acid by Butyrivibrio fibrisolvens, J. Biol. Chem. 241 (1966) 1350-1354.

[28] Kulmyrzaev A., Dufour E., Determination of lactulose and furosine in milk using frontface fluorescence spectroscopy, Lait 82 (2002) 725-735.

[29] Lopez C., Influence de la nature de l'interface matière grasse/eau de laits reconstitués sur la cinétique de coagulation et les caractéristiques du coagulum, Mémoire de DEA, Université de Bordeaux, France, 1997.

[30] Mariaca R.G., Berger T.F.H., Gauch R. Imhof M.I., Jeangros B., Bosset J.O., Occurrence of volatile mono-and sesquiterpenoids in highland and lowland plant species as possible precursors for flavor compounds in milk and dairy products, J. Agric. Food Chem. 45 (1997) 4423-4434.

[31] Martin B., Ferlay A., Pradel P., Rock E., Grolier P., Dupont D., Gruffat D., Besle J.M., Ballot N., Chilliard Y., Coulon J.B., Variabilité de la teneur des laits en constituants d'intérêt nutritionnel selon la nature des fourrages consommés par les vaches laitières, in: Proceedings of IX. Rencontres Rech. Ruminants, Paris, France, 2002, pp. 347-350. 
[32] Mazerolles G., Devaux M.F., Duboz G., Duployer M.H., Mouhous Riou N., Dufour E., Infrared and fluorescence spectroscopy for monitoring protein structure and interaction changes during cheese ripening, Lait 81 (2001) 509-527.

[33] Mazerolles G., Devaux M.F., Dufour E., Qannari E.M., Courcoux, Ph., Chemometric methods for the coupling of spectroscopic techniques and for the extraction of the relevant information contained in the spectral data tables, Chem. Intel. Lab. Syst. 63 (2002) 57-68.

[34] Miquel Becker E., Christensen J., Frederiksen C.S., Haugaard V.K., Front-face fluorescence spectroscopy and chemometrics in analysis of yogurt: Rapid analysis of riboflavin, J. Dairy Sci. 86 (2003) 2508-2515.

[35] Prache S., Priolo A., Tournadre H., Jailler R., Dubroeucq H., Micol D., Martin B., Traceability of grass-feeding by quantifying the signature of carotenoid pigments in herbivores meat, milk and cheese, in: Durand J.L., Emile J.C., Huyghe C., Lemaire G. (Eds.), Multi-fonction grasslands: quality forages, animal products and landscapes, British Grassland Society, La Rochelle, France, 2002, pp. 592-593.

[36] Safar M., Bertrand P.R., Devaux M.F., Genot C., Characterization of edible oils, butters, and margarines by Fourier transform infrared spectroscopy with attenuated total reflectance, JAOCS 71 (1994) 371-377.

[37] Scehovic J., Jeangros B., Troxler J., Bosset J.O., Effet de la composition botanique des herbages pâturés sur quelques composants des fromages de type L'Etivaz ou Gruyère, Rev. Suisse Agric. 30 (1998) 167-171.

[38] Stanton C., Lawless F., Kjellmer G., Harrington D., Devery R., Connolly J.F., Murphy J., Dietary influences on bovine milk cis-9, trans-11conjugated linoleic acid content, J. Food Sci. (1997) 1083-1086.

[39] Summer A., Franceschi P., Bollini A. Formaggioni P., Tosi F., Mariani P., Seasonal variations of milk characteristics and cheesemaking losses in the manufacture of Parmigiano-Reggiano cheese, Vet. Res. Comm. 27 (2003) 663-666.

[40] Viallon C., Verdier-Metz I., Denoyer C., Pradel P., Coulon J.B., Berdagué J.L., Desorbed terpenes and sesquiterpenes from forages and cheeses, J. Dairy Res. 66 (1999) 319-326.

[41] Wold J.P., Jørgensen K., Lundby F., Nondestructive measurement of light-induced oxidation in dairy products by fluorescence spectroscopy and imaging, J. Dairy Sci. 85 (2002) 1693-1704.

[42] Wu Z., Ohajuruka O.A., Palmquist D.L., Ruminal synthesis. Biohydrogenation and digestibility of fatty acids by dairy cows, J. Dairy Sci. 74 (1991) 3025-3034. 